\title{
Lesbian dalam Pergulatan Gender dan Seksualitas di Sudut Pasar Kartika Niaga, Surabaya
}

\author{
Maria Nala Damayanti \\ Visual Communication Design Department, Faculty of Art and Design \\ Petra Christian University, Surabaya, Indonesia \\ E-mail:mayadki@petra.ac.id
}

\begin{abstract}
The presence of women in same-sex sexual trend in Indonesia is considered unnatural. The actor suffered the injustice of the treatment. Condition that was not expected by the women does not make them desperate but appear to be driving their own to declare independence in the community generally. The research follows the lives of several lesbian experiences tells the respondent. Work and have their own income is the way to survive in the big city and at the same time strengthening their identity is still shrouded. A gender and sexual identity collide and the real personalities of women who never consciously chosen from the beginning. But the pressures and demands of life that makes them exist until now. Authors conducted a simple ethnographic approach was very useful in order to obtain accurate data. The research was conducted in Surabaya and done solely to open our eyes wider to the presence of women with different sexual orientation than most of us. It must be admitted some use of key terms in the analysis may be not too precise, perhaps even often confused as a synonym. Gender identity, sexual-biological, sexual orientation. The third term is still like a new food menu, let alone trying to comment on 'taste'. However, the authors sought to understand this discourse as closely as possible, be descriptive, with the hope of understanding themselves become better writers and story-telling flow, and thus contribute to the realm of gender and sexuality, no matter how small.
\end{abstract}

Keywords: female, lesbian, gender, sexuality

\section{Pendahuluan}

Kehidupan kelompok Lesbian di Indonesia belum dapat diterima secara terbuka oleh sebagian besar masyarakat. Diskriminasi adalah perlakuan yang mereka terima, yang dalam banyak hal merugikan kehidupan pribadi sebagai seorang individu. Lahir dalam lingkungan yang nampaknya 'salah' bagi mereka. Khusus di Indonesia, menurut Saskia Wierenga dalam salah satu dialog Radio Nederland Weredomroep dengan radio Maragita Bandung (18 Desember 2009), ada ideologi kuat bahwa perempuan harus menikah. “... Perempuan yang tidak nikah dianggap kurang komplit, tidak normal. Jadi situasinya sangat sulit bagi perempuan apabila ia seorang lesbian di Indonesia ... “. (http://www.rnw.nl/bahasa-indonesia/).

Lebih jauh Profesor Wieringa juga memaparkan diskriminasi yang dihadapi perempuan lesbian, di tempat kerja, pendidikan, di tempat umum, atau dalam keluarga sendiri. Seperti yang pernah ia alami pada masa mudanya di Belanda. Tapi, demikian Saskia menambahkan, ia tidak menjadi pahit ataupun marah, justru sebaliknya. Pengalaman-pengalaman yang tidak enak itu justru menjadikannya seorang pribadi yang kuat. Bahkan 
kini ia adalah Guru Besar pada studi gender di Universitas Amsterdam. Gambaran singkat tentang dunia lesbian tersebut menunjukkan bahwa masih banyak masyarakat yang belum menerima adanya perbedaan dan karena jumlah minoritas itu cenderung mereka memperoleh tindakan yang tidak menguntungkan. Jangankan di Indonesia, di Belandapun yang masyarakatnya lebih terbuka, ternyata perlakuan yang diterima kelompok ini juga sulit. Bagaimana di situasi di Indonesia sekarang, khususnya bila terjadi dalam keluarga kelompok masyarakat menengah ke bawah ?

Pembahasan berikut ini adalah pembahasan seputar gender dan sekelumit kehidupan sexualitas dari subyek pengamatan, yang secara fisik dikatagorikan memiliki sexual biologis perempuan, dan memilih kehidupan sebagai lesbian. Mengapa kehidupan sexualitas tidak bisa digali lebih mendalam dikarenakan beberapa keterbatasan yang dialami dalam proses observasi langsung maupun tidak. Antara lain ada semacam pagar yang seolaholah membatasi responden dalam memperkatakan kondisi mereka karena konsep diri yang mereka wairisi, dan konsep identitas sex dan gender dalam penerimaan di masyarakat. Sebuah pendalaman atau lebih tepat disebut pengamatan terbatas, atas studi interdisiplin ilmu yang dipelajari melalui teori Queer.

Satu hal yang tidak dapat disangkal dalam teori Queer adalah penggunaan istilah queer yang memiliki asal usul homofobis atau anti-gay yang dalam konteks saat itu bersifat menghina. Namun, kini dengan pendekatan postrukturalis 1980-an lewat dekonstruksi oposisi biner, maka kini istilah queer lebih banyak dipakai dalam berbagai diskusi
(Barry 2010). Kecenderungan orientasi sexual seseorang menjadi latar belakang keberadaan kelompok ini. Berdasarkan skala Kinsey kita ketahui bahwa hal tersebut tidak bersifat tetap dalam umur hidup seseorang, melainkan dapat berubah. Sexualitas itu cair menurutnya. Dalam pengamatan sehubungan dengan analisis kasus ini, ditemukan setidaknya dua alasan berbeda mengenai orientasi sexual subyek-subyek yang kemudian menuntunnya pada peran gender tertentu di masyarakat.

\section{Metodologi}

Pendekatan penelitian ini adalah etnometodologi. Pengamatan langsung dan tidak langsung dilakukan selama satu bulan. Berdasarkan waktu pengamatan ini dirasakan hasil pengamatan dan wawancara dengan responden belum optimal. Namun dengan kerja sama yang terjalin baik serta keterbukaan para nara sumber, latar belakang kehidupan responden perlahan terungkap. Pendalaman kasus ini dilakukan melalui dua cara yaitu 1) Pengamatan dari jarak jauh dalam pengertian melihat dari jauh, tanpa melakukan wawancara, yang dilakukan selama tiga minggu berturut-turut, setiap hari, dan 2) Wawancara secara terpisah dalam empat kali pertemuan dengan dua subyek berbeda, dan sebuah wawancara terakhir yang dilakukan bersama-sama dengan dua responden utama, dan satu responden pendamping.

Para responden ini berasal dari golongan pekerja kelas menengah bawah. Pendapatan yang tidak stabil serta tidak adanya ikatan kerja yang tertulis menyebabkan mereka tidak punya kekuatan hukum apapun yang dapat dipakai untuk membela 
hak mereka sebagai pekerja. Kedua responden perempuan bekerja dalam bidang yang umumnya digeluti laki-laki, yakni dunia perparkiran. Pendapatan mereka tidak tetap, lebih kurang Rp.

800.000 per bulannya. Pekerjaan yang sangat bergantung pada kebaikan hati atau kemurahan hati seseorang yang mereka sebut sebagai Bos. Bos adalah orang yang bertanggung jawab dalam keamanan pasar, dan ialah yang bisa mempekerjakan mereka. Tetapi usulan siapa orang yang direkomendasi tetap datang dari sesama pekerja. Sehingga mereka yang bekerja di tempat ini biasanya telah saling mengenal sebelumnya. Tidak ada aturan kerja tertulis, yang ada hanyalah saling pengertian antara sesama pekerja untuk menalangi kekurangan setoran bila penghasilan harian tidak mencukupi jumlah tertentu, sebagaimana ditetapkan Bos. Jumlah setoran harian Rp. 85.000. sisa jumlah tersebut menjadi pendapatan mereka dan dibagi secara merata di antara sesama tukang parkir. Saat ini ada tiga orang perempuan yang menjadi penjaga parkir tetap. Seorang perempuan dan seorang laki-laki sebagai cadangan petugas parkir, yang bertugas parkir apabila ada yang berhalangan. Umumnya tempat kerja di dunia perparkiran dengan lingkungan kerja yang panas, berada di bawah terik matahari bisa jadi adalah alasan pekerja perempuan kurang atau bahkan tidak meminatinya. Namun kondisi ini nampaknya tidak berlaku disini.

Pasar Kartika Niaga, Kebraon berada di daerah Kecamatan Karang Pilang, Surabaya adalah lokasi pekerjaan responden. Perparkiran ditempat ini tidak dilengkapi tiket untuk para pengguna jasa. Jam kerja mereka dari pukul 04.30 s/d 16.30 WIB.
Hari kerja adalah satu minggu penuh, tanpa hari libur. Seperti telah disebutkan di atas saat ini ada tiga perempuan yang bekerja sebagai tukang parkir, yaitu Pe, suku Jawa (39 tahun, sebagai responden pertama), An, suku Madura (45 tahun, sebagai responden kedua) dan Ina (30 tahun). Responden An yang baru bekerja satu tahun juga menggantikan seorang pekerja lain yang juga berpenampilan dan berperilaku tomboy bernama Gan (20 tahun). Pe, An dan Gan berpenampilan tomboy. Sedangkan Ina tidak demikian. Ina dan Gan hanya menjadi responden pendukung, karena keterbatasan waktu penggalian data lapangan.

\section{Hasil dan Pembahasan}

Foucault menyebutkan istilah biopolitical body dari laki-laki dan perempuan, dimana hal ini ditandai oleh pengalaman masa lalu, dan muncul karena hasrat dan ketakutan dalam diri seseorang, maka kemudian inilah yang akan menentukan masa depan mereka (Foucault, 'Nietzsche, Genealogy, History', in P. Rabinow (ed.) The Foucault Reader: Penguin: 76-100). Ini bisa dipahami merujuk pengalaman dua orang responden, Pe (39 tahun) dan An (45 tahun), sehubungan dengan bagaimana mereka mengidentifikasi diri mereka hari-hari ini. Pe adalah seorang tukang parkir dengan identitas sexual (biologis) perempuan. Setidaknya ia tidak keberatan ketika disapa 'mbak', bisa dianggap sebagai sebuah konfirmasi tidak langsung. Dalam kesehariannya ia selalu berpakaian t-shirt yang dibalut jaket (berbahan kaos), sepatu sepatu sandal karet, celana ketat, berambur sangat pendek seperti model rambut laki-laki dan mengenakan topi. 
Memiliki kebiasaan merokok. Kalau berjalan ia tampak membusungkan atau mencondongkan dadanya (yang secara sekilas tidak menunjukkan tonjolan payudara). Kakinya agak terbuka ketika berjalan, terkesan 'cuek'. Komunikasi dengan pengunjung (parkir) sangat minim. Nyaris tidak berbicara ketika melayani konsumen. Untuk pandangan sekilas ia tampak keras dan kaku. Ia tidak berdandan seperti kebanyakan perempuan pekerja, bedakpun tidak. Ia menyadari akan kesukaan berpakaian dan berperilaku seperti lazimnya anak laki-laki, semenjak usia sekolah dasar, akunya. Responden ini tidak sempat menamatkan pendidikan dasarnya, tetapi ia telah menyadari dirinya yang condong ke lelaki-lelakian dalam hal berpakaian dan perilaku, sejak usia dini tersebut. Terhadap kecenderungannya tersebut, iapun pernah mendapat perlakuan tidak menyenangkan dari kedua orang tuanya, yakni berupa tindakan pembakaran semua pakaian miliknya, yang dianggap adalah pakaian laki-laki (merepresentasi anak laki-laki). Ia dianggap aneh, perempuan kok berpakaian seperti laki-laki, kata keluarganya. Pe juga mendapat perlakuan pelarangan keluar rumah pada jam-jam tertentu, sedangkan saudaranya yang laki-laki tidak mengalami hal yang sama. Ayahnya mendidik dengan sangat keras, demikian menurutnya. Ayahnya mengalami moral panic ketika berhadapan dengan anak dengan kelakuan yang dianggap ada di luar kewajaran. Menghadapi itu nampaknya Pe tidak kemudian berubah menjadi seperti harapan ayahnya, seorang perempuan dengan gaun. Bahkan akhirnya keluarganya menyadari kondisinya, dan lalu seolah-olah membiarkan saja, selama dianggap tetap bisa menjaga 'nama baik' keluarga. Nama baik seperti apa yang dimaksud tentu tidak mudah dipahami. Tetapi dari sini terlihat jelas keberadaannya seperti sebuah ancaman bagi keluarga. Setidaknya dengan Pe keluar meninggalkan rumah keluarga, ia telah dianggap tidak membuat masalah lagi bagi keluarga besarnya, demikian penjelasannya.

Moral panic yang ditunjukkan ayahnya memperlihatkan reaksi atas sesuatu hal yang mengganggu norma bahkan mengancam apa yang dipercaya sebagai kebenaran (konstruksi esensial). Keluarganya jelas tidak dapat membedakan sexual biologis dan identitas gender. Sebuah cermin masyarakat yang merupakan hasil konstruksi, namun telah terinternalisasi sedemikian dalam sehingga menjadi semacam ide suci, yang harus dijaga sedemikian rupa. Berdasarkan cerita dan penampilannya, responden nampaknya mengadopsi berbagai penampilan laki-laki yang dianggap maskulin sebagai identitas dirinya, atau bentuk proklamasi identitas gendernya, terutama kepada keluarganya, selanjutnya kepada lingkungan yang lebih luas.

Penjelasan reponden di atas menguatkan hal sebagaimana yang diungkapkan oleh Judith Butler, bahwa teori feminis yang memisahkan sex dan gender telah membantah penyebab yang mengatur peran gender seorang perempuan dalam masyarakat akibat identitas sexual biologisnya. Teori fenomenologi tentang bentuk tubuh manusia juga dikaitkan untuk membedakan berbagai sebab akibat variasi fisiologis dan biologis yang menyusun eksistensi dan makna yang terkandung dalam konteks pengalaman hidup. Refleksi MerleauPonty's dalam “The Phenomenology of Perception" 
mengungkapkan bahwa keberadaan sex pada tubuh manusia adalah "an historical idea rather than a natural species" dan tentang gender, menurutnya adalah "an historical situation rather than a natural fact”. Maka apa yang sebagian besar kita yakini sekarang, seperti binari oposisi yang membagi sex dan gender kedalam dua bagian yakni laki-laki dan perempuan, bahwa laki-laki lebih sesuai untuk urusan external atau 'publik' dan perempuan lebih cocok untuk urusan internal atau 'domestik' (rumah tangga), bahwa perempuan harus bergaun, tidak boleh yang lain, karena tidak menunjukkan siapa dirinya (secara sexual biologis), bahwa perempuan harus feminin, dan laki-laki harus maskulin. Hal-hal tersebut bisa jadi bukan sebuah kenyataan tetapi adalah sebuah ide yang lebih bersifat sejarah. Menurutnya juga tubuh adalah satu set kemungkinan penanda (signifies) yang akan terus menerus direalisasi. (Maurice Merleau-Ponty, "The Body is its Sexual Being," in The Phenomenology of Perception, trans. Colin Smith (Boston: Routledge and Kegan Paul, 1962 dalam Judith Butler, "Performative Acts and Gender Constitution: An Essay in Phenomenology and Feminist Theory" (1988), hal 2-3). Pe menjadi contoh bagaimana sexual biologisnya tidak mengendalikan identitas gendernya, bahkan sejak usia dini (kanak-kanak).

Sejalan dengan klaim Simone de Beauvoir dalam "The Second Sex", bahwa jenis kelamin dan gender adalah sebuah situasi yang bersifat sejarah daripada sebuah fakta alami. Karena itu Butler berusaha menemukan, dengan cara apa gender dikonstruksi melalui perilaku fisik, dan mencari kemungkinan-kemungkinan mengalami transformasi gender lewat seperangkat tindakan.
Selanjutnya menurut Butler realitas gender adalah sebuah performa atau penampilan yang disengaja sebagai ekspresi gender atau identitas dan yang sekaligus mengkonfirmasi akan identitas gender yang diharapkan seseorang. Gender itu sendiri adalah sesuatu yang mendahului berbagai tindakan terhadap postur tubuh dan gestur tertentu, yang lalu dikenali dan dipahami bahwa hal itu berkorelasi dengan sex biologi. (hal 7-8,). Lihat penegasannyan Butler dalam Gender Trouble (1990),

performative thesis : Identity is the repeated stylization of the body, a set of repeated acts within a highly rigid regulatory frame that congeal over time to produce the appearance of substance, of a natural sort of being' (..). Gender is 'always a doing, though not a doing by a subject who might be said to preexist the deed' (33).

Pengulangan tindakan dan perilaku yang dirasakan nyaman tersebut kemudian mengantar kepada keberlanjutan yang melaluinya terpenuhi hasrat dalam dirinya. Pe dan maskulinitasnya dalam hubungan sosialnya beserta pekerjaan yang ia geluti selama lebih kurang sepuluh tahun ini ternyata sangat mengokohkan eksistensi identitas gendernya, persis seperti apa yang dikemukakan Butler.

Pe juga mengistilahkan dirinya sebagai cewek tomboy. Ia mengaku tidak pernah tertarik kepada perempuan. Juga tidak pernah berpikir untuk menikah. Beberapa waktu lalu ia mengaku punya pasangan, dimana ia bertanggung jawab atas beberapa pengeluaran utama pasangannya. Setiap tiga hari ia akan pulang ke Tuban mengunjungi pasangannya yang bekerja sebagai purel. Sebelumnya ia pernah berpacaran dengan seorang perempuan yang bersuami (bekerja di Jakarta, secara 
teratur pulang ke Surabaya). Tinggal di daerah Kebraon. Setiap hari ia pulang ke rumah pasangannya selama suami pasangannya tersebut bekerja di luar kota. Pasangannya ini juga memiliki penghasilan tetap sebagai pembantu/ penjaga rumah orang. Kisah terakhirnya ini memperlihatkan bagaimana pasangan lesbian tidak melulu berhubungan dengan satu sex biologis saja, yang oleh Julia Suryakusuma disebut kehidupan ganda. Secara terang sebagai heterosexual dan secara gelap sebagai homosexual. Selanjutnya, tentang bagaimana perilaku sexualnya, tidak ia ceritakan secara terbuka. Dalam salah satu sesi wawancara, sambil 'senyum-senyum' ia mengatakan 'oh itu rahasia ...' Ini menunjukkan baginya, hal tersebut dianggap sebagai wilayah privat, yang mungkin akan mengganggu kenyamanannya bila diketahui orang lain. Namun ia mengakui dalam berhubungan sexual selalu mencapai tingkat kepuasan tertentu. Jawaban inipun ia jelaskan sambil tersenyum. Sejauh ini bisa saja wawancaraini adalah batas privasinya, yang tidak ingin ia buka lebih jauh.

Lain halnya dengan responden kedua An. Seorang dengan sexual biologis perempuan. Seperti halnya responden pertama ia tidak berkeberatan disapa 'mbak'. Penampilan umunya kelaki-lakian, maskulin. Cara berjalan lambat dan berhati-hati. Posisi tubuh tegak, tetapi membusung. Rambut pendek. Berpakaian t-shirt serta bertopi, dipadu dengan celana jeans ketat model sekarang, ditutup jaket kulit hitam, dan sepatu kets. Tidak berdandan sama sekali. Dalam menjalankan tugasnya ia tidak banyak berbicara dengan pengunjung. Secara umum tampak pendiam bahkan 'dingin' kepada tamu.
Seorang perokok berat. Peminum minuman keras dalam suatu kurun waktu. (Sekurangnya selama empat tahun, ketika bekerja sebagai waitress). Dalam profesinya sebagai tukang parkir, model pakaian sekarang dianggap paling sesuai, praktis, juga dapat melindungi diri dari sengat matahari. Beberapa profesi lainnya pernah ia jalani. Sebelum bekerja sebagai tukang parkir ia pernah menjalani pekerjaan sebagai penjual sayur, pembantu rumah tangga dan waitress. Pakaiannya kala itu tetap menggunakan rok dan blus, serta berambut panjang. Namun ia mengakui, telah punya pasangan sesama wanita ketika itu. Dari penuturan panjangnya tentang latar belakang kehidupannya, diketahui bahwa pengalaman menikah dua kali yang berakhir perceraian telah meninggalkan rasa sakit yang dalam. Sehingga kini ia hanya mengubur angan-angan untuk bersuami kembali dan hidup 'normal' seperti orang lain. Apa yang ia maksud dengan hidup normal adalah menikah dengan lakilaki, dan kemudian memiliki anak. Secara tidak langsung ia menyadari penuh bahwa pilihan hidupnya sekarang 'tidaklah normal'. Tetapi ia menegaskan bahwa pilihan hidup yang sekarang dirasa jauh lebih nyaman dan membawa ketenangan.

Pilihan hidup dengan kondisinya sekarang mempunyai konsekuensinya sendiri. Seperti yang dikatakan oleh Eve Sedgwick dalam Epistemology of The Closet (Barry 171-172), keterbukaan mereka yang lesbian atau gay hanya kepada kelompok tertentu yang dipercaya, tentunya yang dianggap tidak merugikan posisinya. Jelas ini bukan hal yang mudah bahkan rumit bagi mereka. Terlebih sebagaimana dialami An. Perubahan orientasi sexual 
dari heterosexual kepada homosexual dari An lalu disertai perubahan peran gender dari peran sebagai istri dari suami dalam hubungan heterosexual, dengan segala atribut dan perilakunya, kepada peran suami dari pasangan homosexual, yang tentunya juga punya resiko dan konsekuensinya tersendiri. Pengalamaan responden kedua yang diterangkan berikut ini, menunjukkan bagaimana pengalaman hidup seseorang berpengaruh atas keputusan perubahan orientasi sexual dan identitas gender seseorang, bahkan membuatnya merasa lebih baik dalam kehidupan sekarang.

An mengungkapkan, bahwa usia 17 tahun telah ia awali dengan memiliki pasangan perempuan yang diakuinya sebagai pacar. Hubungan pertama tersebut berlangsung selama delapan tahun yang ia jalani dalam profesi tukang sayur. Akhir hubungan tersebut terjadi karena pacarnya akhirnya menikah dengan laki-laki. Rasa sakit yang tersisa akibat pengalaman itu nampaknya belum hilang hingga ketika menuturkan kisahnya ini. An mengatakan ia kerap menolak ajakan bertemu dengan pasangan lamanya, meskipun ia tetap dihubungi untuk sekedar tetap berteman. Ada ikatan 'rasa sayang' tertentu masih ada diantara mereka, menurutnya. Hubungan lain yang juga diakui olehnya adalah hubungan yang masih berlanjut sampai sekarang dengan seorang perempuan yang jauh lebih muda, yang bernama Id (suku Manado) yang yang bekerja sebaga penjual martabak dan kue-kue lain, yang kini bertempat tinggal di daerah Perak. Empat tahun hubungan ini dilakukan dengan sepengetahuan keluarga masing-masing. Pasangannya ini secara terbuka meminta ijin kepada kedua keluarga besarnya untuk menjalin hubungan persahabatan (pacaran ?) dengan An. Selanjutnya, sifat ringan tangan yang selalu ditunjukkan Id terhadap keluarganya menyebabkan An semakin menyayanginya, dan hubungan ini semakin kuat dan erat, menurutnya, karena ia pun melakukan demikian terhadap keluarga Id. Anpun sangat menghargai Id karena sifat murah hatinya, yang ditunjukkan antara lain dengan menabung sisa belanjanya untuk membelikan hand phone (salah satu dari dua miliknya sekarang) untuknya. Oleh karena itu An merasa 'eman' dan sayang karena hubungan tersebut 'seolah-olah' telah 'direstui' dan rukun. An mengaku tidak pernah marah kepada pasangannya, kecuali menegur dengan kata-kata yang sopan, yang menunjukkan tingkat kedewasaan tertentu. Ikatan tertentu yang terjalin di antara keduanya memperlihatkan adanya bentuk ketergantungan tertentu yang kemudian mengikat mereka. Terhadap pertanyaan kemungkinan menikah langsung dijawab oleh An dengan katakata 'tidak bisa', karena pernikahan pasangan lesbi hanya bisa terjadi di luar negeri, demikian penjelasannya. Konsep menikah yang ia miliki tentu saja sebagaimana pasangan hetero menikah, lebih kurang seperti hal yang pernah ia alami. Terhadap pertanyaan menikah dengan pasangan hetero, inipun ditanggapi dengan ungkapan “... untuk apa kalo nanti disakiti lagi “. Jelas, pengalaman yang kurang menguntungkan baginya telah membentuk sikap menolak pasangan hetero.

Sebagai pasangan yang lebih dominan, ia mengakui secara teratur memberikan sebagian pendapatannya kepada pasangannya, untuk menunjukkan tanggung jawabnya. Sikap ini membuatnya merasa nyaman, ditambah fakta 
bahwa pasangan yang terakhir ini sangat manja dan bergantung kepadanya. Dalam mengungkapkan rasa sayang, An mengaku ia tidak terlalu memaksa, karena alasannya takut menyakiti hati pasangannya. Setidaknya ciuman perpisahan selalu mereka lakukan sebelum salah satu dari mereka bepergian. Tetapi mereka kerap bermesraan di tempat tertentu yang tidak terlihat umum.

\section{Lesbian Dalam Hubungan Sosial}

Status kedua hubungan khusus pertemanan antara wanita dari kedua responden di atas, kita kenal sebagai pasangan lesbian. Kedua responden menyebut diri sebagai 'hunter', yang berarti perempuan yang bergaya dan berpenampilan seperti laki-laki. Para hunter umumnya menyebut pasangannya sebagai 'istri' kepada perempuan pasangannya, demikian penuturan terpisah keduanya. Masing-masing mereka dengan latar belakang pengalaman hidupnya memberi alasan mengapa kini mereka memilih hidup dalam kondisi demikian. Bergaul dengan wanita, dan tertarik membina hubungan lebih jauh dengan golongan ini, menjadi salah satu kesamaan keduanya. Homoeroticism yang kini mereka jalani datang dari dua pengalaman yang berlainan, yang berkaitan dengan pengalaman hidup langsung atau tidak, sebagaimana penuturan keduanya.

Dalam usia mendekati separuh baya sekarang, dan berdasarkan pengakuan mereka, telah memiliki setidaknya dua pasangan berbeda bagi An, dan tiga pasangan berbeda bagi Pe. Kenyataan yang mereka jalani sekarang ini jelas bukan hal yang mudah. Mereka akui menjalani hubungan ini tidak bisa dilakukan secara terbuka kepada lingkungan dimana mereka berada. Pandangan masyarakat yang tidak bisa menerima mereka membuat mereka tertutup dan membatasi diri dalam bergaul. Kesadaran yang ada ini bisa jadi didasarkan pada pengalaman antara sesama mereka, yang mana seringkali dipandang sebelah mata atau 'aneh', menurut istilah An. Antara lain melalui ungkapan pelarangan berteman oleh anggota keluarga terdekat mereka, dengan mereka yang dianggap tomboy, seperti dirinya. Hal ini dialami sendiri oleh An. Sejak itu An lebih berhati-hati dalam berhubungan dengan orang lain, yang ia anggap normal, dan cenderung menjadi tertutup. Ini sejalan dengan apa yang diungkapkan Steven Seidman dalam Teori feminis (2006, Volume: 7, Edisi: 1, Penerbit: SAGE Publications, Hal: 105-121), bahwa heteroseksualitas telah dilembagakan dan difokuskan secara eksklusif pada perannya dalam mengatur homoseksualitas. Konstruksi sosial ini telah mengakar kuat dalam struktur masyarakat. Meskipun berbasis pada sex biologis, sex dan gender adalah kontruksi sosial bahkan politik, yang telah diorganisasikan ke dalam sistem kekuasaan yang mendukung dan menghargai individu dan kegiatan tertentu, sambil menghukum dan menekan yang lain, sebagaimana diungkapkan Foucault. Akibatnya masyarakat dengan nilai yang dianutnya sekarang, berpandangan sebagai yang paling benar, dan berhak menilai orang lain yang berbeda sebagai suatu hal yang keliru atau salah. Dan bila kita lebih jauh melihat hal ini bagaimana kelompok masyarakat tertentu bahkan mengambil tindakan fisik mengusir kegiatan organisasi dari kelompok yang mereka anggap salah tersebut, pada peristiwa 
pengusiran anggota konferensi gay di Hotel Oval awal tahun 2011 .

Responden pertama, Pe punya sifat yang berbeda dengan responden kedua, An. Ia lebih eksrovert. Secara cepat ia bisa bergaul dengan orang baru. Bagaimana menjalin hubungan dengan pasangannyapun ia terlihat tidak canggung untuk bercerita. Ini nampak antara lain dalam model pacaran yang dilakukan secara terbuka di tempat umum. Dalam hal ini di area parkir kompleks pertokoan dan perkantoran. Dalam tiga minggu pengamatan terhadap responden ini, nampak jelas lebih ada keberanian pada diri Pe untuk menunjukkan identitasnya. Pada satu sisi ia berhatihati terhadap lingkungan baru namun pada sisi lain, pengalaman mengajarkan bahwa lingkungan perparkiran adalah lingkungan paling aman untuk mengekspresikan diri dalam batasan tertentu. Pengalaman keseharian mereka membentuk sebuah pola kebiasaan sebagai bentuk pertahanan diri atas represi atau diskriminasi yang mereka terima. Bila pengalaman berperilaku sebagai laki-laki telah lama dijalani maka ekspresi yang keluar sepertinya telah mampu mengatasi problem. Bagi Pe problem terbesarnya adalah pekerjaan. Tanpa itu hidupnya sangat sulit. Kondisi sekarang dengan pekerjaan yang tetap membuat ia merasa nyaman. Bagi Pe perempuan tomboy seperti dirinya tidak mudah memperoleh pekerjaan, sehingga pilihan saat ini sebagai tukang parkir, dirasa paling sesuai untuknya. Lingkungan yang telah lama ia geluti selama ini adalah dunia tukang parkir, dan pengalaman kerja lima tahun terakhir di tempat yang sama bisa jadi membuat ia merasa nyaman dalam menyatakan identitas atau orientasi sexualnya.
Situasi yang berbeda terjadi pada An, tidak serta merta mengabaikan lingkungan dengan pendapat dan pandangan mereka. Kehati-hatian penting baginya untuk didahulukan mengingat pilihan hidupnya yang ia anggap 'berbeda' dari orang kebanyakan. Identitas gender yang berubah di sepanjang hidup An meneguhkan ucapan Judith Butler bahwa lesbianisme bukanlah identitas yang stabil dan hakiki, bahkan bisa diperebutkan dan direvisi. Latar belakang pengalamannya, dari penganut heteronormatif kepada homonormatif menjadikannya sebagai pasangan lesbian yang nyaman dalam dominasinya sekarang ini. Naluri sebagai ibu dari seorang anak perempuan remaja, dan dorongan orientasi sexual biologisnya sekarang, membawanya kepada kondisi yang nampaknya bertolak belakang dengan kehidupan lamanya. Di satu pihak, ia tetap bertanggung jawab atas anaknya yang sedang ia titipkan pada pesantren, dilain pihak, ia tetap menjalin hubungannya dengan pasangan perempuannya sekarang. Tidak secara lugas anaknya mengetahui hubungan persahabatan ini, namun menurut pengakuan An sejauh ini anaknya belum menunjukkan keberatan apapun. Hal ini dibuktikan dengan sekurangnya tiga kali Lebaran bersama dikampung halamannya, dan tidak menimbulkan masalah dalam keluarga tersebut. Dengan keluarga besarnyapun selama ini 'hampir' tidak ada masalah. Yang penting saling menghormati dan tidak saling ikut campur urusan pribadi, demikian menurutnya. Ada saling menyadari dan tumbuh pengertian antar sesama anggota keluarga besarnya, sehingga ia tidak merasa terbuang dari lingkungan keluarga besarnya tersebut. Cerita di atas menunjukkan bahwa masih ada semacam pantangan atau tabu untuk 
membicarakan perbedaan dirinya dengan anggota keluarga yang lain. Masalah ini sebenarnya sensitif bagi mereka. Namun demi ketenangan keluarga mereka memilih untuk tidak membicarakannya secara terbuka lebih jauh lagi.

Perlakuan tidak menyenangkan dari lingkungan yang dialami responden dapat dilihat sebagai cermin masyarakat yang melihat hubungan pertemanan di antara perempuan sebagai hal yang aneh, bahkan kegagalan. Seperti diungkapkan oleh Pe bahwa di dalam keluarganya ia menyebut diri sebagai anggota keluarga yang dianggap 'tidak jadi orang', seperti tujuh saudara kandung lainnya. Situasi yang lebih menguntungkan dialami An, karena ia tidak pernah terusir dari keluarga besarnya.

Pe merasa 'tidak menjadi orang', sementara An merasa tidak bisa hidup 'normal' seperti layaknya orang kebanyakan. Istilah normal dan tidak ini nampaknya merupakan buah dari pendidikan yang mereka terima selama ini. Keluarga tempat mereka dibesarkan adalah keluarga heterosexual sehingga konsep mereka tentang apa yang disebut kebenaran mencuat dengan pola heterosexual. Serta sangat patriarkis.

Inilah yang mungkin menjadi keterbatasan yang menyebabkan kelompok orientasi sexual yang berbeda atau minoritas kurang diterima masyarakat. Sejalan dengan apa yang dikemukakan BJD Gayatri, seorang pendiri LSM Lesbian pertama di Indonesia bahwa mainstream masyarakat sudah dibentuk sejak seseorang kecil. Maka, nilai-nilai yang sudah tidak relevan lagi dengan perkembangan zaman akan masih terus-menerus mengakar kuat jika kita tidak bisa membuka pikiran dan wawasan kita, termasuk cara pandang kita tentang seksual minoritas (Jurnal Perempuan, 14 April 2008)

\section{Simpulan}

Kecenderungan mengasosiasi sifat feminim pada perempuan dan maskulin pada laki-laki bisa jadi membatasi perilaku dan perkembangan individu. Bahwa laki-laki yang disebut sebagai suami bertanggung jawab sebagai kepala keluarga, sedikit banyak diadopsi oleh kelompok lesbian, dengan tetap memakai istilah 'suami' dan bertanggung jawab membagi penghasilan kepada ‘istri'nya. Baik Pe maupun An nampaknya mereka terjebak dalam performa maskulinitas laki-laki, dan terperangkap kecenderungan patriarki dalam gender mereka sekarang. Mereka berpakaian seperti laki-laki dan berperilaku juga seperti laki-laki. Menjalani pekerjaan yang banyak digeluti laki-laki, punya pasangan yang mereka sebut sebagai istri yang mereka sebut 'perempuan banget', menyadari ada kewajiban untuk membiayai pasangannya, adalah sepenggal kehidupan yang mereka jalani sekarang. Gambaran pasangan lesbian yang berusaha mandiri ditengah banyak penolakan atas identitas mereka. Satu hal lain yang menarik adalah para pasangan lesbian (yang disebut istri) di atas adalah orangorang yang juga mandiri, punya penghasilan sendiri, dan tidak hidup bergantung sepenuhnya kepada pasangan atau yang mereka sebut sebagai suami. Perjuangan identitas untuk sekedar hidup di tengah perbedaan, yang patut dihargai, ditengah masyarakat yang lebih banyak menuntut pengakuan dan pelayanan. Tidak ada keluhan, meskipun terhegemoni oleh arus besar yang belum menghargai 
pluralitas khususnya dalam hal identitas sexual dan gender. Sebagai catatan perjuangan kecil di tengah carut marut ide budaya tentang potensi dan identitas sexual serta gender yang mungkin menguntungkan 'penguasa'.

Kisah ini mengkonfirmasi Julia Suryakusuma dalam Prisma (Juli 1999), meskipun homosexualitas terdapat dalam banyak masyarakat dunia, tidak merugikan orang lain, mereka masih dianggap aib dan mengancam, sehingga mengalami diskriminasi dalam hubungannya dengan ide mayoritas sosial.

\section{Daftar acuan}

Butler, Judith, 1988, "Performative Acts and Gender Constitution: An Essay in Phenomenology and Feminist Theory”, New York: Routledge.

Butler, Judith, 1990, Gender Trouble: Feminism and the Subversion of Identity. London; New York: Routledge,

Foucault, 'Nietzsche, Genealogy, History', in P. Rabinow (ed.) The Foucault Reader: Penguin Merleau-Ponty, Maurice, 1962, “The Body is its Sexual Being," in The Phenomenology of Perception ,trans. Colin Smith. Boston: Routledge and Kegan Paul.

Prisma, Juli 1999. Jakarta: LP3ES

Seidman, Steven, Teori feminis, Volume: 7, Edisi: 1, Penerbit: SAGE Publications, 2006 (http://dx.doi.org/10.1177/146470010606146 2), (http://www.deepdyve.com/lp/sage/gendersexuality-and-heterosexuality-the-complexityand-limits-of-2yXZK3rEw9) http://www.rnw.nl/bahasa-indonesia/radioshow/swieringa-semua-punya-hak-untuk-hidup- akses 30 Juni 2011).

http://arsip.jurnalperempuan.com/index.php/j po/comments/lesbian_normal_dan_tidak_berd osa/ akses 30 Juni 2011)

http://www.deepdyve.com/lp/sage/gender-sexualityand-heterosexuality-the-complexity-and-limitsof-2yXZK3rEw9 akses 30 Juni 2011) 